\title{
El instituto, la familia y el tabaquismo en adolescentes
}

\section{School, family and adolescent smoking}

\author{
Aina Yañez ${ }^{\star}$; Alfonso Leiva ${ }^{\star *}$; LuCia GorReto ${ }^{\star \star *}$;

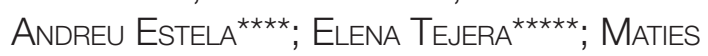 \\ TORRENT $T^{\star \star \star \star \star \star}$
}

*Fundació d'Investigació Sanitaria Illes Balears (FISIB), Hospital Son Espases **Unidad de Investigación Gerencia de Atención Primaria de Mallorca, Ib-Salut ${ }^{* * *}$ Centro de Salud Emili Darder, Atención Primaria de Mallorca, Ib-Salut ${ }^{\star \star \star \star \star}$ Centre de Salut dalt Sant Joan, Atención Primaria de Menorca, lb-Salut

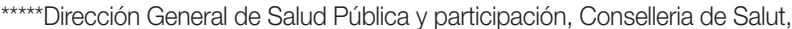
Família i Benestar Social ${ }_{* \star \star \star \star \star}$ Area de Salut de Menorca, Ib-Salut

Enviar correspondencia a:

Alfonso Leiva,

Unidad de Investigación Gerencia de Atención Primaria de Mallorca, lb-Salut,

C/ Reina Esclaramunda 9, Palma de Mallorca, Spain,

E-mail: aleiva@ibsalut.caib.es

\section{Resumen}

El entorno socio-cultural es un importante factor implicado en el inicio de tabaquismo durante la adolescencia. El inicio del tabaquismo ocurre casi exclusivamente en esa etapa. En este contexto, el objetivo era analizar la asociación entre factores escolares y familiares y tabaquismo en adolescentes, mediante un estudio transversal a una muestra aleatoria de 16 centros escolares de las Islas Baleares, donde participaron un total de 3673 escolares de Educación Secundaria Obligatoria (ESO) y 530 profesores de dichos centros. La prevalencia de tabaquismo regular (al menos un cigarrillo por semana) fue de 4,8\% entre los estudiantes de primero de ESO, el 11,6\% entre los estudiantes de segundo de ESO, el 14,1\% entre los estudiantes de tercero de ESO, el 20,9\% entre los estudiantes de cuarto de ESO y del 22\% entre los profesores.

Entre los estudiantes de primero y segundo año, había asociaciones independientes entre el tabaquismo regular $y$ : poder fumar en casa, pertenecer a una familia monoparental, tener una mala relación con los padres, bajo rendimiento académico, falta de interés en los estudios y la propia percepción de los profesores de consumo de tabaco por parte del profesorado en presencia de alumnos.

Entre los alumnos de tercero y cuarto de ESO las variables que se mostraron independientemente asociadas al tabaquismo regular fueron: una mala relación con los padres, poder fumar en casa, bajo nivel académico, mayor transigencia del centro escolar sobre la mala conducta del estudiante y el propio centro escolar.

Las políticas y prácticas escolares podrían relacionarse con el comportamiento del adolescente frente al consumo de tabaco, independientemente de los factores individuales y familiares.

Palabras claves: tabaquismo, adolescencia, centro escolar, profesores, familia

\section{Abstract}

The socio-cultural environment is an important factor involved with the onset of smoking during adolescence. Initiation of cigarette smoking occurs almost exclusively during this stage. In this context we aimed to analyze the association of school and family factors with adolescent smoking by a cross-sectional study of 16 secondary schools randomly selected from the Balearic Islands involved 3673 students and 530 teachers.

The prevalence of regular smoking (at least one cigarette per week) was 4.8\% among first year students, 11.6\% among second year students, 14.1\% among third year students, 20.9\% among fourth year students and 22\% among teachers.

Among first and second year students, there were independent associations between regular smoking and adolescents' perception of being allowed to smoke at home, belonging to a single parent family, poor relationship with parents, poor academic performance, lack of interest in studies and teachers' perception of smoking in the presence of pupils.

Among third and fourth year students, there were independent associations between regular smoking and poor relationship with parents, adolescents' perception of being allowed to smoke at home, poor academic performance, lack of control over student misbehavior and the school attended.

The school policies and practices affect student related health behavior regarding smoking, independent of individual and family factors.

Key words: smoking, adolescence, schools, teachers, family. 
S moking is a risk factor for several chronic diseases and the main cause of avoidable mortality in developed countries (Peto, 1994; Peto et al., 1996). Despite a decline in the prevalence over the last decades, smoking is still accepted as a normal social activity (Pérez-Milena A et al., 2012) and teen smoking rates remain high.

The factors associated with the onset of tobacco consumption can be grouped into three categories (Flay, 1999): 1) individual factors, corresponding to the intrinsic factors of each individual, including age and cognitive, emotional and biological factors; 2) factors associated with immediate social context, corresponding to the setting closest to each teenager, including the attitudes and behaviors of relatives and friends related to smoking; and 3) factors associated with socio-cultural environment, this level include those factors that make smoking appear less socially acceptable as local laws or school policy on smoking.

Studies analyzing the influence of individual factors and immediate social context on the onset of smoking have found that tobacco consumption is associated with low academic performance (O'Loughlin, Karp, Koulis, Paradis, y Difranza, 2009), a positive attitude toward smoking (Nebot et al., 2004; Gomez, Barrueco, Maderuelo, Aparicio y Torrecilla, 2008), belonging to a single parent family (Yanez et al., 2006), smoking by parents and siblings, and lack of attention and supervision by parents. Moreover, many studies have found that adolescent smoking may be influenced by peer group smoking (Richardson, Radziszewska, Dent, y Flay, 1993; Alexander, Piazza, Mekos, y Valente, 2001; de Vries, Engels, Kremers, Wetzels, y Mudde, 2003; Flay et al., 1994).

Recent studies have highlighted the influence of sociocultural environment on the onset of smoking. The prevalence of adolescent smoking has been found to vary among school centers (Aveyard, Markham, y Cheng, 2004) and attending a school that tolerates smoking has been associated with a significantly higher percentage of students that start consuming tobacco (O'Loughlin et al., 2009; Barnett et al., 2007; Moore, Roberts, y Tudor-Smith, 2001; Piontek et al., 2008; Wakefield et al., 2000). Moreover, a longitudinal study performed at secondary schools in England (Aveyard et al., 2005) showed that the school center alone, irrespective of the characteristics of the students, influenced the percentage of smoking students.

These inter-school variations in smoking may be due via indirect paths, such as smoking by teachers and the level of compliance with smoking bans in school centers. Although there is little evidence of the latter, the percentage of teachers who smoke, as reported by the center directors, was significantly associated with the percentage of students who have smoked once (Barrueco et al., 2000).

The main objective of our study was to analyze the association between school and family characteristics and smoking in adolescents in compulsory secondary education.

\section{Methods}

\section{Study population}

The data of this cross-sectional study were collected in school centers involved in Compulsory Secondary Education
(CSE) in the Balearic Islands (Spain) during the years 20092010. Using a single-stage conglomerate procedure in proportion to the size of the school center, we randomly selected 18 centers of 137 centers involved in CSE of Balearic islands; of these, 16 (89\%) agreed to participate. These included 7 state-assisted centers and 9 state schools from Mallorca, Menorca and Ibiza. Sample size was calculated to estimate the prevalence of smoking in the CSE with a precision of $\pm 5 \%$. Prior to data collection, a letter was sent to the parents of each adolescent, explaining the objective of the study and requesting consent. The study was ethically approved by the Commission of Primary Care Investigation of Mallorca. The Local Education Authority of the Balearic Islands collaborated to allow access to the centers and to invite them to participate.

\section{Data Collection}

Data were collected from teachers by means of a questionnaire distributed at each center. In addition to determining age, sex and smoking (daily smoker, occasional smoker, former daily smoker, former occasional smoker, or never smoker), this questionnaire asked about their perceptions of teacher smoking at school regularly during working hours (yes/no) and in the presence of pupils (yes/no).

Data were subsequently collected from students using a questionnaire filled out in the classroom in the presence of a previously trained survey taker, who explained the questionnaire and answered any questions. The following questions were included: age (in years), sex (boy/girl), normal living conditions (father/mother/other), academic level compared with the rest of the class (good/average/ bad), interest shown in classes (much/ some/ little/ none), general opinion about school (very good/good/ neutral/ bad/ very bad), general relationship with teachers at school (very good/good/ neutral/ bad/ very bad), general relationship with parents (very good/good/ neutral/ bad/very bad), and perception of free time spent with parents (very good/ good/ neutral/ bad/ very bad). The questionnaire also asked students if their parents were angry if they knew that they smoked (did/ did not become angry/ did not know), academic level of their father and mother, smoking status of their father and mother (yes/no), and if they could smoke at home (yes/no). Students also filled out a questionnaire on smoking, adapted from a previously validated questionnaire for adolescents (Comín $\mathrm{E}$, Torrubia Beltri R, Mor Sancho J, Villalbi Hereter JR, y Nebot Adell $M, 1997)$.

The questionnaires administered to the teachers and the students were self-administered, voluntary and anonymous.

Finally, we interviewed by telephone the academic director of each school to determine the age of the center (in years), the number of secondary students registered, tolerance for bad behavior by students (not tolerated / depends on teacher ( moderately tolerated) and if sanctions were applied to students and teachers for smoking on school grounds (yes/no). 


\section{Data analysis}

Responses to questionnaires were digitalized and captured using a program that recognized written characters and subsequently verified manually (Teleform v7.0).

A regular smoker was considered to be any adolescent who smoked at least one cigarette per week regularly. Teachers were considered smokers if they declared they were current smokers (daily or occasional). Ex-smoker were consider any adolescent or teacher that currently were not a regular smoker and smoke at least one cigarette per week in the past.

A bivariate analysis, using the Chi squared test, was performed to study the association between smoking in adolescents and each independent factor. The Pearson coefficient correlation was used to analyze the correlation between the percentage of adolescents who smoked and the percentage of teachers who thought that colleagues smoked regularly in front of students during working hours.

A random-effects multilevel logistic regression model was used to determine whether the contextual effect of the center was related to student smoking, using center as a second level variable (random effect) and, as first level variables, the independent factors associated with smoking in the bivariate analysis (RabeHesjeth S y Slymen, 2008). The odds ratios and median odds ratios (MOR)(Merlo et al., 2006) were used to measure the association between each variable and smoking in adolescents.

Statistical analyses were performed separately in first and second year students (early adolescence) and in third and fourth year students (intermediate adolescence), because significant interactions were found between school year and variables associated with smoking. All statistical analyses were performed using the Stata v11.0 program, with statistical significance set at $p<.05$.

\section{Results}

\section{Participation of and smoking by students}

Of the 4025 students registered in the 16 selected centers, 3721 (92\%) participated in the study. The main cause (98\%) of nonparticipation in the study was absence from school on the day the questionnaire was administered. Valid data for analysis were obtained from 3673 students.

The mean \pm SD age of the students was $14.4 \pm 1.4$ years, with $48.5 \%$ girls and $51.5 \%$ boys. The majority of students (61.2\%) attended a public school. Of the participating students, $8.8 \%$ (95\% confidence interval $[\mathrm{Cl}], 7.9 \%-9.7 \%$ ) declared that they smoked daily, 3.6\% (95\% Cl, 3.0\%-4.2\%) smoked weekly, and $5.7 \%(95 \% \mathrm{Cl}, 4.9 \%-6.4 \%)$ smoked occasionally (a few times per month). In addition, $11.8 \%(95 \% \mathrm{Cl}, 10.7 \%-12.8 \%)$ said they were former smokers and $70.1 \%(95 \% \mathrm{Cl}, 68.6 \%-71.6 \%)$ had never smoked. There were no statistically significant differences between boys and girls; however, the prevalence of regular smoking (daily or weekly) increased significantly over time, being $4.8 \%$ during the first year, $11.6 \%$ during the second year, $14.1 \%$ during the third year, and $20.9 \%$ during the fourth year $(p<0.05)$.
The mean consumption of cigarettes by daily adolescent smokers was $9 \pm 8$ (Huber's M-estimator 7,6) and the mean age of onset $12.6 \pm 1.8$ years. Most smokers (75\%) obtained cigarettes from tobacco vending machines and 47\% from tobacconists. Minor adolescents, however, more frequently obtained tobacco from friends and/or relatives, including 68\% of first and second year students and 56\% of third and fourth year students $(p<0.05)$.

\section{Participation of and smoking by teachers}

Of the 846 teachers in the 16 schools, 530 (62.6\%) participated in the survey; of these, $45 \%$ were men and $55 \%$ women, and their mean age was $39 \pm 9$ years. The prevalence of smoking among teachers was $22 \%$ ( $14 \%$ daily, $8 \%$ occasionally), whereas $28 \%$ were ex-smokers. Sixty two per cent thought teachers smoked on school grounds during working hours and $22 \%$ though teachers smoked in the presence of students.

\section{Association between student smoking and school and familial variables}

The prevalence of adolescent smoking among school centers varied considerably, from $5 \%$ to $21 \%$. There was a significant correlation between the percentage of teachers reporting that they though that colleagues smoked at school in the presence of students and the percentage of smoking by first and second year students $(r=0.68 ; p<.01$; Figure 1$)$. However, there was no association between the percentage of smoking teachers and the percentage of smoking students.

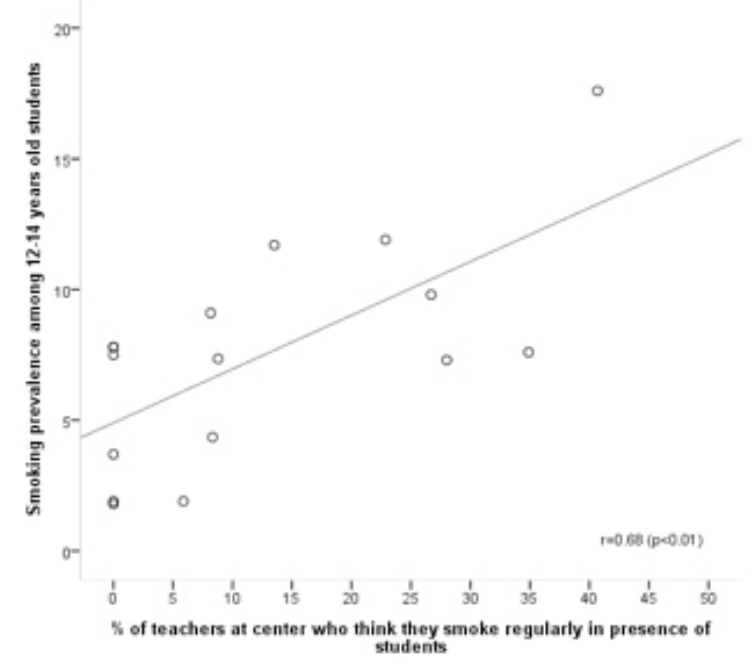

Figure 1. Correlation between the percentage of teachers who think they smoke in the presence of students at school, and the percentage of first and second year CSE students who smoked.

Tables 1 and 2 show smoking in adolescents by year in relationship to individual, school and family characteristics. Both during early (first and second year students) and intermediate (third and fourth year students) adolescence, various factors associated with the school and family settings were significantly associated with smoking. 
Table 1

Regular smoking by adolescents according to personal characteristics and school year

\begin{tabular}{|c|c|c|}
\hline & $\begin{array}{l}\text { 1st-2nd CSE } \\
\mathrm{n} / \mathrm{N}(\%)\end{array}$ & $\begin{array}{l}\text { 3rd-4th CSE } \\
\mathrm{n} / \mathrm{N}(\%)\end{array}$ \\
\hline \multicolumn{3}{|l|}{ Sex } \\
\hline Male & 79/1039 (7.6) & 150/857 (17.5) \\
\hline Female & 86/960 (9) & 140/817 (17.1) \\
\hline \multicolumn{3}{|l|}{ Academic level $\left.\right|^{*} \mp$} \\
\hline Good & $31 / 813(3.8)$ & $68 / 619(11)$ \\
\hline Average & 84/981 (8.6) & $156 / 844(18.5)$ \\
\hline Bad & 48/179 (26.8) & 60/196 (30.6) \\
\hline \multicolumn{3}{|c|}{ Opinions about school ${ }^{*} \mp$} \\
\hline Very good & 19/361 (5.3) & $7 / 129(5.4)$ \\
\hline Good & 70/1073 (6.5) & 128/937 (13.7) \\
\hline Neutral & $44 / 432(10.2)$ & $119 / 470(25.3)$ \\
\hline Bad/Very bad & 29/ 117 (24.8) & $32 / 132(24.2)$ \\
\hline \multicolumn{3}{|l|}{ Academic interest ${ }^{*} \mp$} \\
\hline High-Sufficient & $32 / 868(3.7)$ & $66 / 574(11.5)$ \\
\hline Some & $90 / 956(9.4)$ & 180/942 (19.1) \\
\hline Little-None & $41 / 154(26.6)$ & $41 / 145(28.3)$ \\
\hline \multicolumn{3}{|c|}{ Relation with teachers ${ }^{*} \mp$} \\
\hline Very good & 16/414 (3.9) & $32 / 275(11.6)$ \\
\hline Good & $81 / 1149(7)$ & 165/1072 (15.4) \\
\hline Neutral & $48 / 367(13.1)$ & $74 / 278(26.6)$ \\
\hline Bad/Nery Bad & $17 / 52(32.7)$ & 14/42 (33.3) \\
\hline \multicolumn{3}{|l|}{ Type of center $\mp$} \\
\hline Public & $116 / 1245(9.3)$ & 198/1013 (19.5) \\
\hline State-assisted & $49 / 755(6.5)$ & 92/664 (13.9) \\
\hline \multicolumn{3}{|c|}{ Percentage of smoker-teachers in center } \\
\hline \multirow[t]{2}{*}{$<21 \%$} & $83 / 979(8.5)$ & $148 / 857(17.3)$ \\
\hline & 82/1021 (8.0) & $142 / 820(17.3)$ \\
\hline \multicolumn{3}{|c|}{$\begin{array}{l}\text { Percentage of teachers smoking } \\
\text { In presence of students* }\end{array}$} \\
\hline \multicolumn{3}{|c|}{ Yes } \\
\hline \multirow[t]{2}{*}{ No } & 106/1053 (10.1) & 154/908 (17) \\
\hline & $59 / 947(6.2)$ & 136/769 (17.7) \\
\hline \multicolumn{3}{|c|}{$\begin{array}{l}\text { Application of sanctions to teachers for } \\
\text { Smoking in center }\end{array}$} \\
\hline Yes & $50 / 527(9.5)$ & 69/372 (18.5) \\
\hline No & $115 / 1473(7.8)$ & $221 / 1305(16.9)$ \\
\hline \multicolumn{3}{|l|}{ Age of center (years) } \\
\hline$<21$ & $42 / 540(7.8)$ & $56 / 385(14.5)$ \\
\hline $21-50$ & $55 / 592(9.3)$ & $97 / 435(22.3)$ \\
\hline $51-60$ & 39/408 (9.6) & 89/458 (19.4) \\
\hline$>60$ & $29 / / 460(6.3)$ & 48/399 (12.0) \\
\hline \multicolumn{3}{|l|}{ No students* } \\
\hline$<350$ & $26 / 500(5.2)$ & $86 / 467(18.4)$ \\
\hline $351-400$ & 55/592 (9.3) & 61/321 (19.0) \\
\hline $401-650$ & $39 / 369(10.6)$ & $72 / 440(16.4)$ \\
\hline$>650$ & $45 / 539(8.3)$ & $71 / 449$ (15.8) \\
\hline \multicolumn{3}{|l|}{ Tolerance of bad behavior $\mp$} \\
\hline Not tolerated & $108 / 1437(7.5)$ & 194/1294 (15) \\
\hline Depends on teacher & $33 / 356(9.3)$ & $51 / 242(21.1)$ \\
\hline Moderately tolerated & 24/207 (11.6) & 45/141 (31.9) \\
\hline
\end{tabular}

*Significant differences for weekly smoking in 1-2 year

$\mp$ Significant differences for weekly smoking in 3-4 year
Table 2

Regular smoking by adolescents according to familial characteristics and school year

\begin{tabular}{|c|c|c|}
\hline & $\begin{array}{l}\text { 1st-2nd CSE } \\
n / N(\%)\end{array}$ & $\begin{array}{l}\text { 3rd-4th CSE } \\
\mathrm{n} / \mathrm{N}(\%)\end{array}$ \\
\hline \multicolumn{3}{|l|}{ Type of family*t } \\
\hline Two parents & $90 / 1491(6.0)$ & $207 / 1312(15.8$ \\
\hline Single parent & $75 / 509(14.7)$ & $83 / 365(22.7)$ \\
\hline \multicolumn{3}{|c|}{ Relationship with parents* $\mp$} \\
\hline Very good & $74 / 1185(6.2)$ & $105 / 790(13.3)$ \\
\hline Good & 49/601 (8.2) & 122/678 (18) \\
\hline Regular & $30 / 149(20.1)$ & $42 / 161(26.1)$ \\
\hline Bad/Nery bad & $9 / 29(31.0)$ & $16 / 31(51.6)$ \\
\hline \multicolumn{3}{|l|}{ Smoking by parents ${ }^{*} \mp$} \\
\hline Neither parent smokes & $51 / 973(5.2)$ & $120 / 888(13.5)$ \\
\hline One parent smokes & $64 / 653(9.8)$ & 98/506 (19.4) \\
\hline Both parents smoke & $50 / 374(13.4)$ & $72 / 283(25.4)$ \\
\hline \multicolumn{3}{|c|}{ Evaluation of free time with parents* $\mp$} \\
\hline Very good & $46 / 751(6.1)$ & 48/369 (13) \\
\hline Good & $59 / 915(6.4)$ & $147 / 930(15.8)$ \\
\hline Neutral & $46 / 257(17.9)$ & $77 / 324(23.8)$ \\
\hline Bad/Nery bad & 10/39 (25.6) & 13/33 (39.4) \\
\hline \multicolumn{3}{|c|}{ Frequency of conversations on health with parents } \\
\hline Frequently & $28 / 412(6.8)$ & $59 / 352(16.8)$ \\
\hline Sometimes & $84 / 1086(7.7)$ & $141 / 927(15.2)$ \\
\hline Nearly never/never & $49 / 458(10.7)$ & $84 / 378(22.2)$ \\
\hline \multicolumn{3}{|c|}{ Attitude of parents to smoking by children* $\mp$} \\
\hline Would get angry & $65 / 1336(4.9)$ & 86/918 (9.4) \\
\hline Do not know & $42 / 426(9.9)$ & $70 / 454(15.4)$ \\
\hline Would not get angry & $51 / 166(30.7)$ & $118 / 258(45.7)$ \\
\hline \multicolumn{3}{|c|}{ Could/can smoke at home* $\mp$} \\
\hline No & $88 / 1642(5.4)$ & $114 / 1266(9)$ \\
\hline Yes & $72 / 269(26.8)$ & $160 / 349(45.8)$ \\
\hline \multicolumn{3}{|c|}{ Educational level of father $\mp$} \\
\hline None & 15/187 (8) & $39 / 146(26.7)$ \\
\hline Primary school & $24 / 288(8.3)$ & 63/323 (19.5) \\
\hline Secondary school & $59 / 741(8.0)$ & $113 / 696(16.2)$ \\
\hline University & $38 / 565(6.7)$ & $55 / 406(13.5)$ \\
\hline \multicolumn{3}{|c|}{ Educational level of mother $\mp$} \\
\hline None & $14 / 150$ (9.3) & 29/126 (23) \\
\hline Primary school & 23/268 (8.6) & 59/302 (19.5) \\
\hline Secondary school & $71 / 773(9.2)$ & $131 / 745(17.6)$ \\
\hline University & $38 / 594(6.4)$ & $53 / 403(13.2)$ \\
\hline
\end{tabular}

Multivariate analysis using a multilevel logistical regression model showed no contextual effect of "school center" during early adolescence; for these students, we used a simple logistical regression model with no random effects (Table 3 ). Factors associated with smoking included low academic level, living in a single parent family, ability to smoke at home, relationship with parents, and greater percentage of teachers who though colleagues smoked regularly in the presence of students.

In third and fourth year students, the contextual variable "center" was significantly associated with smoking, with a MOR of 1.6. Individual variables significantly associated with smoking in this age group included low academic level, ability to smoke at home and having a neutral/ bad relationship with parents. School tolerance of bad behavior was also significantly associated with smoking in the adjusted model, and explained part of the variability among centers (models A and C; Table 4). 
Table 3

Association between regular smoking by adolescents and school and family variables in first and second year students (12-14 years old). $N=1999$

\begin{tabular}{|c|c|}
\hline Characteristics & OR (IC 95\%) \\
\hline \multicolumn{2}{|l|}{ Age } \\
\hline & $1.95(1.62-2.35)$ \\
\hline \multicolumn{2}{|l|}{ Sex } \\
\hline Male & 1 \\
\hline Female & $1.45(1.00-2.10)$ \\
\hline \multicolumn{2}{|l|}{ Academic level } \\
\hline Good & 1 \\
\hline Regular & $1.79(1.13-2.83)$ \\
\hline Bad & $3.73(2.10-6.64)$ \\
\hline \multicolumn{2}{|l|}{ Academic interest } \\
\hline High-sufficient & 1 \\
\hline Some & $2.07(1.10-3.89)$ \\
\hline Little-None & $2.56(1.20-5.44)$ \\
\hline \multicolumn{2}{|l|}{ Family type } \\
\hline Two parents & 1 \\
\hline Single parent & $1.93(1.32-2.82)$ \\
\hline \multicolumn{2}{|l|}{ Relationship with parents } \\
\hline Very good/good & 1 \\
\hline Neutral/ bad-very bad & $2.14(1.31-4.49)$ \\
\hline \multicolumn{2}{|l|}{ Could/can smoke at home } \\
\hline No & 1 \\
\hline Yes & $4.76(3.23-7.035)$ \\
\hline \multicolumn{2}{|c|}{$\begin{array}{l}\% \text { of teachers at center who think they } \\
\text { smoke regularly in presence of students }\end{array}$} \\
\hline$<10 \%$ & 1 \\
\hline$>=10 \%$ & $1.72(1.17-2.53)$ \\
\hline
\end{tabular}

Binomial logistic regression of fixed effects.

\section{Discussion}

We found that the prevalence of smoking increased with age from 12 and 16 years, from 5\% to 21\%, reaching a percentage similar to that in adults. The behavior of teachers, the school attended and the attitudes of parents were all significantly associated with the onset of tobacco consumption.

Adolescents buy tobacco habitually from tobacconists and vending machines despite being underage. Although studies in different countries are very heterogeneous, in general the youngest adolescents tend to obtain cigarettes from friends whereas older adolescents buy cigarettes themselves (Robinson, Dalton, III, y Nicholson, 2006), findings similar to our results.

One of the most interesting results of our study was the association between socio-cultural environmental factors and adolescents smoking. We found that teachers smoking in the presence of students are related to smoking onset. Similarly to previous studies (Murray, Kiryluk, y Swan, 1984; de Moor et al., 1992), there was no correlation between the percentages of teachers and students that smoked but a study in Finland (Virtanen et al., 2009) showed a discreet association. Interestingly, a study performed in 1979 showed a close association between smoking by teachers and adolescents (Bewley, Johnson, y Banks, 1979), but this may have been due to a strong correlation
Table 4

Association between regular smoking in adolescents and school and family variables. In third and fourth year students (14-16 years old); Models A-C. N=1586; 16 School centers.

\begin{tabular}{|c|c|c|c|}
\hline Characteristics & $\begin{array}{l}\text { Model A } \\
\text { OR (IC 95\%) }\end{array}$ & $\begin{array}{l}\text { Model B } \\
\text { OR (IC 95\%) }\end{array}$ & $\begin{array}{l}\text { Model C } \\
\text { OR (IC 95\%) }\end{array}$ \\
\hline Age & $1.49(1.26-1.75)$ & $1.48(1.26-1.74)$ & $1.49(1.27-1.75)$ \\
\hline \multicolumn{4}{|l|}{ Sex } \\
\hline Male & 1 & 1 & 1 \\
\hline Female & $1.09(0.81-1.49)$ & $1.09(0.80-1.49)$ & $1.11(0.81-1.50)$ \\
\hline \multicolumn{4}{|l|}{ Academic level } \\
\hline Good & 1 & 1 & 1 \\
\hline Regular & $1.57(1.11-2.24)$ & $1.57(1.10-2.23)$ & $1.56(1.10-2.22)$ \\
\hline Bad & $2.85(1.77-4.60)$ & $2.86(1.77-4.61)$ & $2.86(1.77-4.60)$ \\
\hline \multicolumn{4}{|l|}{ Relationship with parents } \\
\hline Very good/good & 1 & 1 & 1 \\
\hline Neutral/ bad-very bad & $1.82(1.21-2.75)$ & $1.82(1.21-2.74)$ & $1.84(1.23-2.77)$ \\
\hline \multicolumn{4}{|l|}{ Could/can smoke at home } \\
\hline No & 1 & 1 & 1 \\
\hline Yes & $7.78(5.71-10.60)$ & $7.77(5.70-10.59)$ & 7.67 (5.63-10.45) \\
\hline \multicolumn{4}{|l|}{ Type of center } \\
\hline Public & & 1 & \\
\hline State assisted & & $0.77(0.41-1.45)$ & \\
\hline \multicolumn{4}{|l|}{ Tolerance of bad behavior } \\
\hline Not tolerated & & & 1 \\
\hline Depends on teacher & & & $1.43(0.73-2.82)$ \\
\hline Moderately tolerated & & & $2.62(1.19-5.80)$ \\
\hline \multicolumn{4}{|l|}{ School center variance } \\
\hline ( LR test; $p$-value ) & $0.27 ; p<.001$ & $0.26 ; p<.001$ & $0.16 ; p=.01$ \\
\hline MOR* school center & 1.65 & 1.62 & 1.46 \\
\hline
\end{tabular}

*Median Odds Ratio; Binomial logistic regression of fixed and randomized effects

between smoking in front of students and percentage of smoking teachers at that time. These results suggest that the onset of smoking among adolescents may be influenced more by seeing teachers smoke than by teachers' smoking.

Moreover, another study suggest that smoking by the director may be directly related to compliance with smoking regulations (Murray et al., 1984) because smoking by the center director has also been associated with smoking by students.

Among family factors, we found that the ability of an adolescent to smoke at home was strongly associated with smoking during both early and intermediate adolescence. In contrast, belonging to a single parent family and having a bad relationship with parents were independently associated with smoking by the younger group, but not by the older group. A previous study (Wakefield et al., 2000) showed that the prevalence of adolescent smokers was lower if smoking was not allowed at home, especially if the prohibition was total. A longitudinal study (Sargent y Dalton, 2001) also found that parents' strong disapproval of smoking, independent of whether they smoked, prevented smoking by adolescents. Our results highlight the great importance of parental attitudes to smoking by adolescents. 
In agreement with previous results (Piontek et al., 2008; Jackson, Henriksen, Dickinson, y Levine, 1997), we found that smoking was highest in those with the poorest academic performance, independent of other variables.

The percentage of teachers who smoked in the presence of students was associated by 12-14 year olds whereas school attended was associated with smoking by those aged 14-16 years. This difference may be due to the design of this study. In some schools, smoking policies may have changed over time. Moreover, factors associated with onset and maintenance of a behavior differs. In the younger group, we are likely assessing the factors associated with earlier onset, whereas, in the older group, we are likely assessing the factors associated with later onset and maintenance.

There are two reasons why there may be inter-school variation in smoking prevalence (Aveyard et al., 2005). The first is that there are differences between the populations of students attending schools, for example socio-economical differences. However, in our study after adjusting for parental educational level and other variables related with attitudes and family characteristics there is still an unexplained inter-school variation. The second reason is because some contextual and collective factors influence students independently of compositional risk factors for smoking. Characteristics of each center as relative tolerance of bad behavior could explain partially this variability.

The main limitation of our study was that it was not longitudinal. Thus, we could not determine whether the variables associated with smoking existed prior to smoking by the student. Moreover, our analysis did not control for peer smoking (Aveyard, Markham, y Cheng, 2004), so as not to reduce the possibility of finding effects at the school level. Furthermore characteristic of adolescent and teacher at the individual level were collected among a questionnaire, such type of studies are limited by the subjectivity interpretation of the questions. This limitation may have arisen in the question about perception of teachers who think they smoke in the presence of students at school.

\section{Conclusions}

Smoking prevention and control programs for adolescents should take into account the importance of multiple contextual factors. The first preventive programs centered on the risks of tobacco consumption produced few positive results. The inclusion of training in refusal skills improved these results, but these programs were still far from effective (Thomas y Perera, 2006). An effective program should include components aimed at making educators and families aware of their role model effects on adolescents. Moreover, knowledge about suppliers of tobacco to underage students, as well as the attitudes and habits of the teachers in each school, may be relevant to preventive programs in the community setting.

\section{Competing interests}

None of the authors has any conflicts of interest to declare.

\section{Authors' contributions}

All authors contributed to the conception and design of the study. AY and AL contributed to the acquisition of data. AY performed the statistical analysis and all authors contributed to the interpretation of data. All authors contributed to draft and to the revision of the manuscript for important intellectual content and approved the final version.

\section{Acknowledgements}

This study was supported by grants to Aina Yañez from the Plan de Adicciones y Drogodependencias de las Islas Baleares (PADIB) and Conselleria de Salut i Consum de las Islas Baleares, Spain. The authors want to thank Marina Fernández, Marcos Gorreto, Trinidad Fernández and Maria Moranta for her excellent job contacting and surveying schools. We are specially grateful to all teachers and adolescents participant in this study.

\section{References}

Alexander, C., Piazza, M., Mekos, D. y Valente, T. (2001). Peers, schools, and adolescent cigarette smoking. Journal of Adolescence Health, 29, 22-30.doi: 10.1016/S1054-139X(01)00210-5.

Aveyard, P., Markham, W. A. y Cheng, K. K. (2004). A methodological and substantive review of the evidence that schools cause pupils to smoke. Social Science y Medicine, 58, 2253-2265. doi:10.1016 j.socscimed.2003.08.012

Aveyard, P., Markham, W. A., Lancashire, E., Almond, J., Griffiths, R. y Cheng, K. K. (2005). Is inter-school variation in smoking uptake and cessation due to differences in pupil composition? A cohort study. Health y Place., 11, 55-65. doi:10.1016/j.healthplace.2004.02.001

Barnett, T. A., Gauvin, L., Lambert, M., O'Loughlin, J., Paradis, G. y McGrath, J. J. (2007). The influence of school smoking policies on student tobacco use. Archives of Pediatrics y Adolescent Medicine, 161, 842-848. doi:10.1001/archpedi.161.9.842.

Barrueco, M., Hernandez-Mezquita, M. A., Jimenez-Ruiz, C., Torrecilla, M., Vega, M. T. y Garrido, E. (2000). Attitudes of teachers about tobacco prevention at school. Allergologia et Immunopathologia, 28, 219-224.

Bewley, B. R., Johnson, M. R. y Banks, M. H. (1979). Teachers' smoking. Journal of Epidemiology and Community Health, 33, 219-222.

Comin, E. , Torrubia, R, Mor, J., Villalbi, J. R. y Nebot, M. (1997). The reliability of a self-administered questionnaire for investigation of the level of exercise, smoking habit and alcohol intake in school children. Medicina Clínica, 8, 293-8.

Delegación del Gobierno para el Plan Nacional sobre Drogas (2008). Informe ESTUDES 2008. Encuesta estatal sobre uso de drogas en estudiantes de enseñanzas secundarias. Recuperado de: [http:// www.pnsd.msc.es/Categoria2/observa/pdf/Estudes2008.pdf.].

de Moor, C., Cookson, K., Elder, J. P., Young, R., Molgaard, C. A. y Wildey, M. (1992). The association between teacher attitudes, behavioral 
intentions, and smoking and the prevalence of smoking among seventh-grade students. Adolescence, 27, 565-578.

de Vries, H., Engels, R., Kremers, S., Wetzels, J. y Mudde, A. (2003). Parents' and friends' smoking status as predictors of smoking onset: findings from six European countries. Health Education Research, 18, 627-636. doi: 10.1093/her/cyg032

Flay, B. R. (1999). Understanding environmental, situational and intrapersonal risk and protective factors for youth tobacco use: the Theory of Triadic Influence. Nicotine \& Tobacco Research, 1 (Supp/2), S111-S114. doi: 10.1080/14622299050011911

Flay, B. R., Hu, F. B., Siddiqui, O., Day, L. E., Hedeker, D., Petraitis, J.,... Sussman, S. (1994). Differential influence of parental smoking and friends' smoking on adolescent initiation and escalation of smoking. Journal of Health and Social Behaviour, 35, 248-265.

Gómez, C. G., Barrueco, F. M., Maderuelo, F. A., Aparicio, C. I. y Torrecilla, G. M. (2008). Predictive factors of smoking behaviour in secondary school children. Anales de Pediatría, 68, 454-461. doi:10.1157/13120042

Jackson, C., Henriksen, L., Dickinson, D. y Levine, D. W. (1997). The early use of alcohol and tobacco: its relation to children's competence and parents' behavior. American Journal of Public Health, 87, 35964.

Merlo, J., Chaix, B., Ohlsson, H., Beckman, A., Johnell, K., Hjerpe, P.,... Larsen, K. (2006). A brief conceptual tutorial of multilevel analysis in social epidemiology: using measures of clustering in multilevel logistic regression to investigate contextual phenomena. Journal of Epidemiology and Community Health, 60, 290-297. doi:10.1136/ jech.2004.029454

Moore, L., Roberts, C. y Tudor-Smith, C. (2001). School smoking policies and smoking prevalence among adolescents: multilevel analysis of cross-sectional data from Wales. Tobacco Control, 10, 117-123. doi:10.1136/tc. 10.2.117

Murray, M., Kiryluk, S. y Swan, A. V. (1984). School characteristics and adolescent smoking. Results from the MRC/Derbyshire Smoking Study 1974-8 and from a follow up in 1981. Journal of Epidemiology and Community Health, 38, 167-172.

Nebot, M., Tomas, Z., Ariza, C., Valmayor, S., Lopez, M. J. y Juarez, 0. (2004). Factors Associated With Smoking Onset: 3-Year Cohort Study of Schoolchildren. Archivos de Bronconeumología, 40, 495501.

O'Loughlin, J., Karp, I., Koulis, T., Paradis, G. y Difranza, J. (2009). Determinants of first puff and daily cigarette smoking in adolescents. American Journal of Epidemiology, 170, 585-597. doi: 10.1093/aje/kwp179

Pérez-Milena A., Martínez-Fernández, M. A., Redondo-Olmedilla, M., Nieto C. Á., Pulido I. J. y Gallardo, I. M. (2012). Motivations for tobacco consumption among adolescents in an urban high school. Gaceta Sanitaria, 26, 51-57. doi:10.1016/j.gaceta.2011.03.021

Peto, R. (1994). Smoking and death: the past 40 years and the next 40. British Medical Journal, 309, 937-939.

Peto, R., Lopez, A. D., Boreham, J., Thun, M., Heath, C., Jr., y Doll, R. (1996). Mortality from smoking worldwide. British Medical Bulletin, $52,12-21$.
Piontek, D., Buehler, A., Rudolph, U., Metz, K., Kroeger, C., Gradl, S.,... Donath, C. (2008). Social contexts in adolescent smoking: does school policy matter? Health Educational Research, 23, 1029-1038. doi: 10.1093/her/cym063

Rabe-Hesjeth S y Slymen, D. J. (2008). Multilevel and longitudinal modeling using stata. (2 ed.) Texas.

Richardson, J. L., Radziszewska, B., Dent, C. W. y Flay, B. R. (1993). Relationship between after-school care of adolescents and substance use, risk taking, depressed mood, and academic achievement. Pediatrics, 92, 32-8.

Robinson, L. A., Dalton, W. T. 3rd, y Nicholson, L. M. (2006). Changes in adolescents' sources of cigarettes. Journal of Adolescence Health, 39, 861-867. doi:10.1016/j.jadohealth.2006.06.004

Sargent, J. D. y Dalton, M. (2001). Does parental disapproval of smoking prevent adolescents from becoming established smokers? Pediatrics, 108, 1256-1262. doi: 10.1542/peds. 108.6.1256

Thomas, R. y Perera, R. (2006). School-based programmes for preventing smoking. Cochrane Database System Revision, 3:CD001293. doi: 10.1002/14651858.CD001293.pub2

Virtanen, M., Pietikainen, M., Kivimaki, M., Luopa, P., Jokela, J., Elovainio, M. y Vahtera, J . (2009). Contribution of parental and school personnel smoking to health risk behaviours among Finnish adolescents. BMC Public Health, 9, 382. doi:10.1186/1471-2458-9382

Wakefield, M. A., Chaloupka, F. J., Kaufman, N. J., Orleans, C. T., Barker, D. C., y Ruel, E. E. (2000). Effect of restrictions on smoking at home, at school, and in public places on teenage smoking: cross sectional study. British Medical Journal, 321, 333-337. doi: http://dx.doi. org/10.1136/bmj.321.7257.333

Yanez, A. M., Lopez, R., Serra-Batlles, J., Roger, N., Arnau, A. y Roura, P. (2006). Smoking among adolescents: population study on parental and school influences. Archivos de Bronconeumología, 42, 21-24. 